\title{
THE ROLE OF WATER IN SUPPORTING FOOD SECURITY: WHERE WE ARE AND WHERE WE NEED TO GO
}

\author{
Claudia Ringler, Nicostrato Perez, and Hua Xie
}

Although global annual water availability is largely stable, with small increases as a result of accelerated water cycles under climate change (Oki and Kanae 2006), the demand on water resources has grown substantially over the past 50 years, due to population growth, agricultural and economic growth, and urbanization (WWAP 2016; Bates et al. 2008). This has led to increasing competition across water-using sectors and contributed to severe degradation of water and related ecosystems and biodiversity loss in parts of the globe and, in some cases, outmigration of humans. Higher temperatures, less certain precipitation patterns, as well as shorter, more concentrated rains together with prolonged dry seasons are putting further pressure on available water supplies (Bates et al. 2008; Fishman, Jain, and Kishore 2013; WWAP 2016). All of these developments have put access by farmers to water for food production at risk.

Globally, most crops and livestock are produced using soil moisture that comes from precipitation (also known as rainfed agriculture) (FAO 2011). Rainfed agriculture accounts for approximately 95 percent of the harvested crop area in Africa south of the Sahara, 86 percent in Latin America, two-thirds in the Middle East and North Africa region, half in Asia, and 85 percent of the harvested crop area in high-income countries (Ringler 2017). Conversely, Asia features the world's largest irrigated areas, followed by the Middle East and North Africa regions, and there has been little investment in irrigation in Africa south of the Sahara until recently.

While most crop area is rainfed, the contribution of irrigation to food security has been essential, generating 40 percent of global food production on less than a third of the world's harvested land. For this, irrigation requires large volumes of freshwater. This is reflected in the agriculture sector accounting for approximately 70 percent of global water withdrawals, largely for irrigation but also for livestock watering and aquaculture as well as for more than 80 percent of consumptive water use of withdrawn water (FAO AQUASTAT 
2019; Ringler 2017; WWAP 2019). Irrigated agriculture supports food production in dry seasons, in areas that receive too little rainfall to grow food, and increasingly supplements production in areas with less predictable rainfall. Irrigated yields are generally 30 percent to 60 percent higher than those of rainfed crops, as irrigation supports higher-yielding seeds through improved water control. As a result of growing water variability and climate change, the role of irrigation as a key climate change adaptation strategy is growing in importance (Rosegrant, Ringler, and Zhu 2009; Ringler 2017).

The call for more sustainable food systems and an overall healthier planet, coupled with acute water shortages in cities around the globe, are putting pressure on irrigation water use. At the same time, there are demands for accelerated irrigation development to fuel agricultural and rural growth in areas particularly affected by climate variability and change as well as in those regions where irrigation development has lagged, such as in Africa south of the Sahara (Malabo Montpellier Panel 2018; Vicuña, McPhee, and Garreaud 2012; Olmstead 2013). Given growing pressures on water resources, there is agreement that agricultural water development and management needs to be dramatically improved to meet increased food demands and nutrition goals while also improving the environment. The next section describes the role of irrigation for food security, including through modeling a series of irrigation expansion scenarios. An overview of the key challenges associated with increased irrigation development follows, along with a series of promising solutions. The final section concludes with policy recommendations.

\section{The Role of Irrigation for Food Security}

Climate change exacerbates the adverse effects of growing water scarcity on agricultural productivity through increasing temperatures and changing patterns of precipitation and consequent increased variability in the supply of water (Bates et al. 2008). To assess the role of irrigation expansion for future food security, we use IFPRI's International Model for Policy Analysis of Agricultural Commodities and Trade (IMPACT), a multimarket model that simulates the operation of national and international food markets subject to water and other constraints (Robinson et al. 2015; see Chapter 19 in this volume for additional details). IMPACT takes into account both biophysical factors, such as climate and water availability, and economic factors, such as food prices and food demand, and can thus assess the contribution of changes in irrigation development for key food security parameters under climate change. The climate change scenario chosen for this analysis is the HGEM Global 
Circulation Model with a Representative Concentration Pathway (RCP) 8.5 scenario and a midrange Shared Socioeconomic Pathway scenario (SSP2) (see Chapter 19).

Without climate change (NoCC), average global yields of cereals are projected to increase from 3.3 metric tons per hectare to 4.3 metric tons per hectare between 2015 and 2050. With climate change (the HGEM scenario), global yields are projected to be 9 percent lower, on average, in 2050. Yield declines due to climate change are projected to be largest in the North America region, albeit from high levels, followed by the Latin America and Caribbean region and the South Asia region. Yield declines translate into a projected reduction of global cereal production of 8 percent, with an 18 percent decline in the group of developed countries and a 2 percent decline in the Global South. Production shortfalls put pressure on food prices and dampen demand for food (Figure 20.1).

Irrigation can counteract production declines and associated food price increases under climate change through ensuring that enough water is available during the cropping season, through increased cropping intensity, by expanding the cropping season into the dry season, for example, and through supporting higher yields through more optimal water provision on irrigated lands. However, irrigated area has been expanding only slowly as a result of high investment costs for large-scale irrigation-compared to long-term secular declines in global food prices-due to growing pressure to use water in other sectors and due to growing environmental concerns. As a result, growth in irrigated area is estimated at around 2 million hectares of harvested area a year globally over the next several decades, with growth concentrated in the group of developing countries.

To assess the role of irrigation for agriculture and food security, we simulate three irrigation expansion scenarios under climate change with varying rates of irrigation expansion. In IRREXP_30, we accelerate irrigated area development over baseline expansion to increase irrigated area by 30 percent by 2030 from 2015 levels. In IRREXP_50, global irrigated harvested area grows by 50 percent by 2030 from 2015 levels; and in IRREXP_100, area increases by 100 percent, but over a longer timeframe, from 2015 to 2045 . Figure 20.2 presents changes in total harvested areas as a result of irrigation investment and Figure 20.1 presents associated changes in average crop and in average cereal prices. Under moderately accelerated irrigation development, global irrigated harvested area is estimated to increase by 101 million hectares by 2050, including the conversion of 47 million hectares of rainfed lands. If investments would generate a 50 percent increase in irrigated 
FIGURE 20.1 Projected world prices of food commodities under alternative irrigation expansion scenarios, 2050 (index $2015=1.00$ )

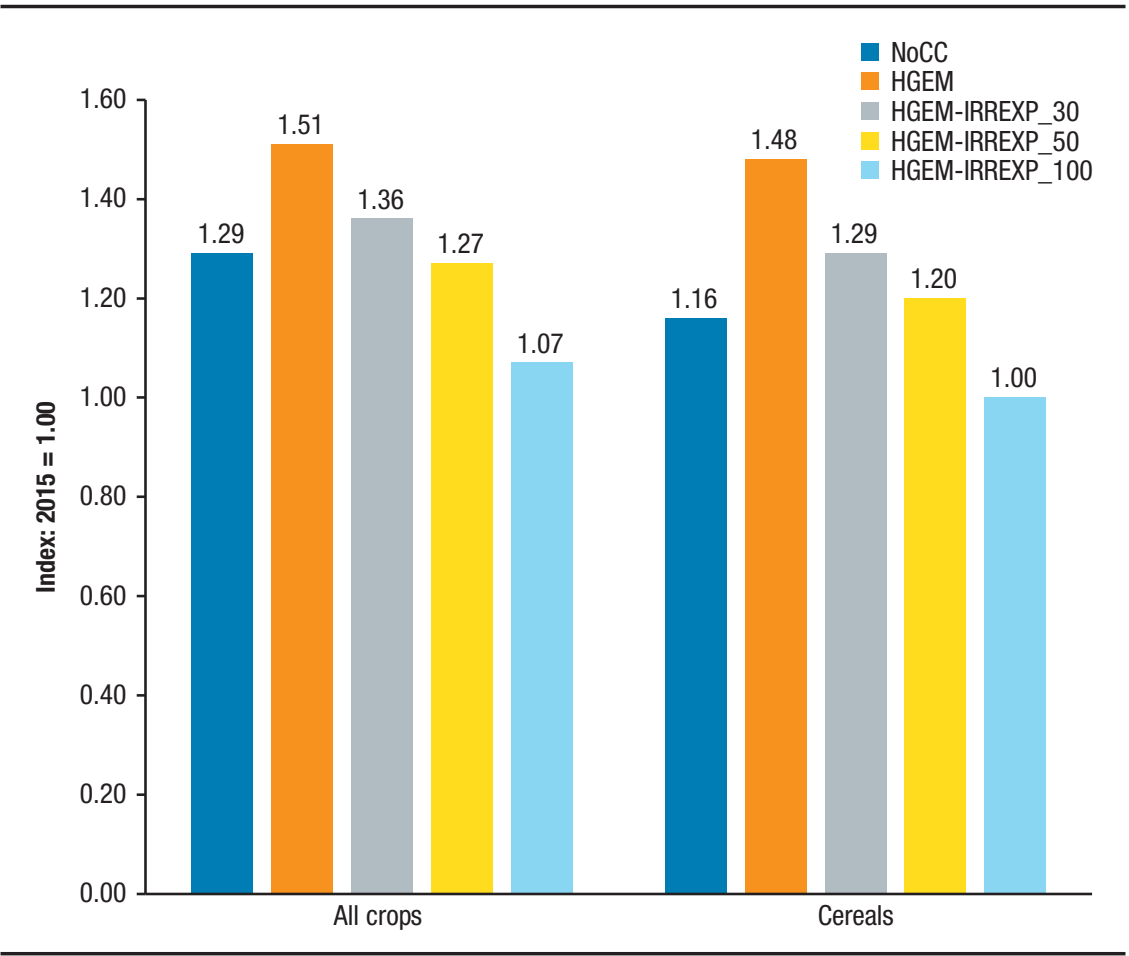

Source: Authors' estimates from IMPACT simulations.

Note: NoCC = no climate change; HGEM = climate change scenario based on the Hadley Centre Global Environmental Model; IRREXP_30 = 30 percent irrigation expansion; IRREXP_50 = 50 percent irrigation expansion; IRREXP_100 = 100 percent irrigation expansion.

area, an additional 165 million hectares of irrigated harvested area would be added, including through the conversion of 73 million hectares of rainfed harvested area. Under the most rapid irrigation development scenario (HGEM_ IRREXP_100), 315 million hectares of irrigated harvested area would be added, including 100 million hectares from conversion of rainfed area.

Increases in irrigated area support substantial increases in food production. Production of all crops is projected to increase by 2.1 percentage points to 7.7 percentage points in 2050 as a result of irrigation expansion; with larger increases in the group of developing countries. As Figure 20.1 shows, an increase of irrigated areas by 50 percent over baseline rates by 2030 can close to reverse food price increases due to climate change. Even larger investments, at 100 percent over baseline increases, can reduce food prices to levels below 
FIGURE 20.2 Changes in harvested irrigated and rainfed areas, alternative irrigation expansion scenarios, 2050
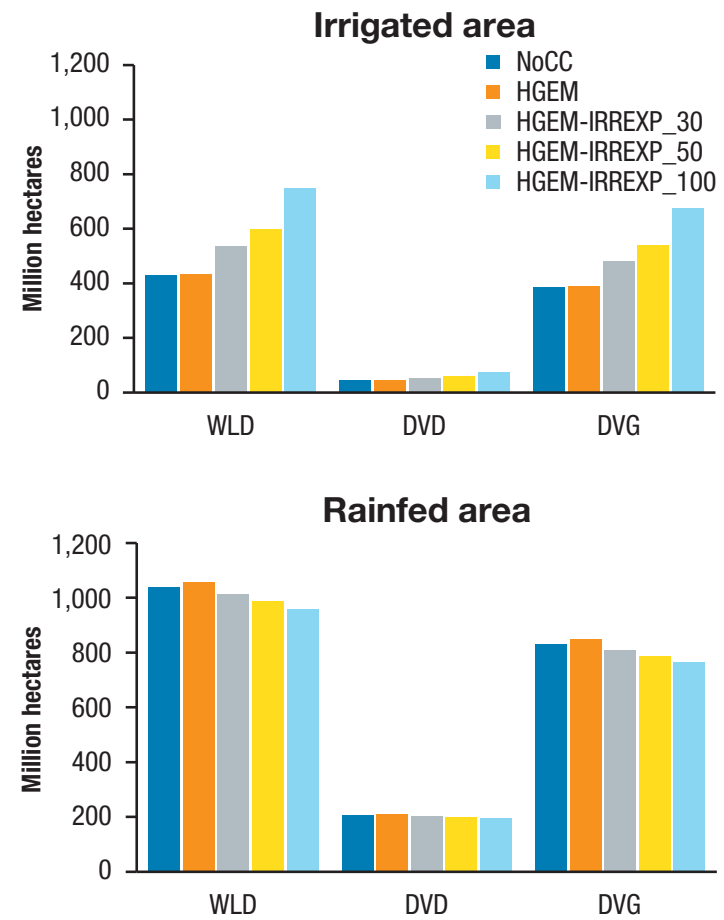

Source: Authors' estimates from IMPACT simulations.

Note: $W L D=$ world; DVD = developed countries; $D V G=$ developing countries; NoCC = no climate change; $\mathrm{HGEM}=$ climate change scenario based on the Hadley Centre Global Environmental Model; IRREXP_30 $=30$ percent irrigation expansion; IRREXP_50 = 50 percent irrigation expansion; IRREXP_100 = 100 percent irrigation expansion.

a NoCC scenario. This suggests that irrigation can make effective contributions to address adverse impacts of climate change.

\section{Global Challenges of Agricultural Water Management}

\section{Water Depletion, Including Groundwater Depletion}

With population and economic growth, water scarcity has been on the rise in many areas around the world and is now often considered to be the single largest water problem (Jury and Vaux 2005). Using water withdrawals as a share of water availability as a water scarcity indicator, Figure 20.3 shows the 
FIGURE 20.3 Water withdrawals as a share of internal renewable water resources at country level, 2010

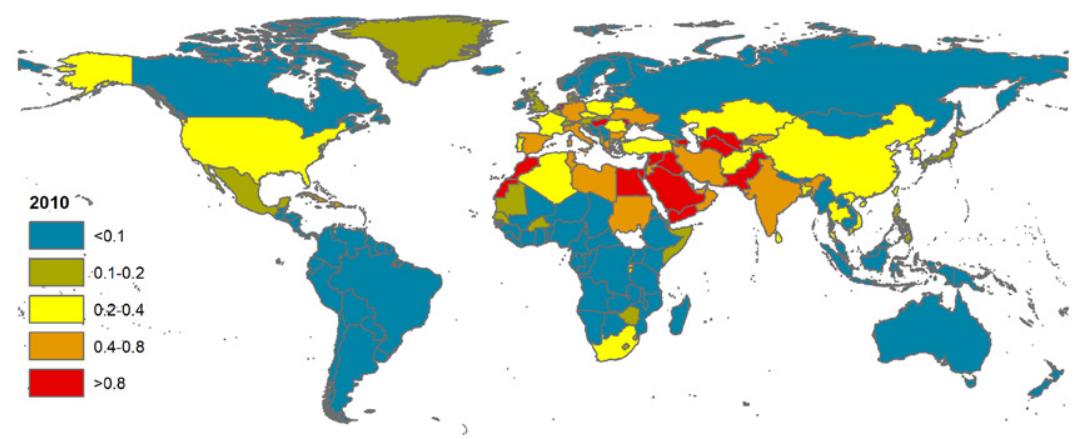

Source: IFPRI IMPACT (2019).

present water scarcity situation at the country level. A country is considered to be under low water stress if its water withdrawal-to-availability ratio is below 0.2 , under moderate water stress if the ratio is between 0.2 and 0.4 , and under severe water stress if the ratio is greater than 0.4 (Alcamo and Henrichs 2002). Following this definition, water stress levels are largest in the Middle East and North Africa region, Pakistan, and selected Central Asian countries, and are also large for selected countries in Europe.

Ringler et al. (2016) estimate that in 2010 one-third of the global population lived in river basins with severe risks of water scarcity (see also Oki and Kanae 2006) and that the share of the population at severe risk was growing dramatically to affect more than half ( 52 percent) of the global population by 2050. In a different estimate, Mekonnen and Hoekstra (2016) find that twothirds of the world's population currently live in areas that experience water scarcity for at least one month a year-focusing attention on the seasonality of water scarcity. However, these water scarcity indictors mask important subnational variations in water availability and access; highly water-scarce countries, such as in the North Africa region, might have adjusted to lower water withdrawal levels, complicating cross-country comparison, and water access by the poorest can be lowest in some of the most water-rich countries, such as the Democratic Republic of the Congo (Mehta et al. 2019). As such, the water scarcity indicator - and indeed any water-related indicatorwould need to be supplemented by additional information for water management investments. 
Agricultural water was traditionally supplied by surface systems through river diversions, or through harnessing seasonal floods (Sojka, Bjorneberg, and Entry 2002). However, groundwater is the largest distributed store of liquid freshwater in the world (Shiklomanov 1993; Gleeson et al. 2015). With technological innovations, groundwater use has been increasing dramatically over the last 50 years, and groundwater depletion and contamination with pollutants and seawater in coastal areas has become a further sign of the growing risks and lack of sustainability of current agricultural water management practices. The most rapid increase in groundwater withdrawals for agriculture has occurred in Asia, where the world's largest irrigated areas are located (Shah et al. 2007). In parts of Asia, large, centralized pumping systems were used in the 1950s and 1960s, often to reduce waterlogging and salinization, such as in the Salinity Control and Reclamation Project (SCARP) of Pakistan (World Bank 1986). With the advent of cheap drilling technologies and more affordable, individual pump sets since the 1970s, combined with a secular decline in investments in public surface systems in Asia, private groundwater-sourced irrigation has rapidly increased and in many instances overtaken large-scale public infrastructure in growth and extent.

The most well-known case of smallholder-led groundwater irrigation is India. According to Mukherji and Das (2014), by 2011-2012 approximately 39 million hectares of the total of 65 million hectares of net irrigated area in India were irrigated with groundwater. Much of this development in India has been due to (1) affordable, individual pump technology; (2) cheap drilling technology; (3) inflexible and unreliable canal irrigation-sometimes coupled with the availability of high water tables due to runoff and seepage and percolation from canal systems; and (4) in several states, access to free electricity for pumping (Mukherji and Das 2014). Smallholder- or farmer-driven developments in South Asia have since been replicated in parts of Southeast Asia, Latin America, and Africa south of the Sahara.

Today, groundwater plays a major role in irrigation and food production globally. More than one-third of the world's 301 million hectares of area equipped for irrigation relies on groundwater. In addition, global consumptive use of groundwater in irrigation is estimated to account for 43 percent of total consumptive irrigation water use (Siebert et al. 2010). Among the top 15 groundwater-using countries in the world, 11 are in Asia. India is the largest groundwater user in the world, abstracting 251 cubic kilometers of groundwater annually, of which 223 cubic kilometers or 89 percent is estimated to be used for irrigation (Figure 20.4). China and the United States are the second and third largest users of groundwater with most of the water extracted used 
FIGURE 20.4 Groundwater extraction by sector in the top 15 groundwater-using countries, 2010 (cubic kilometers)

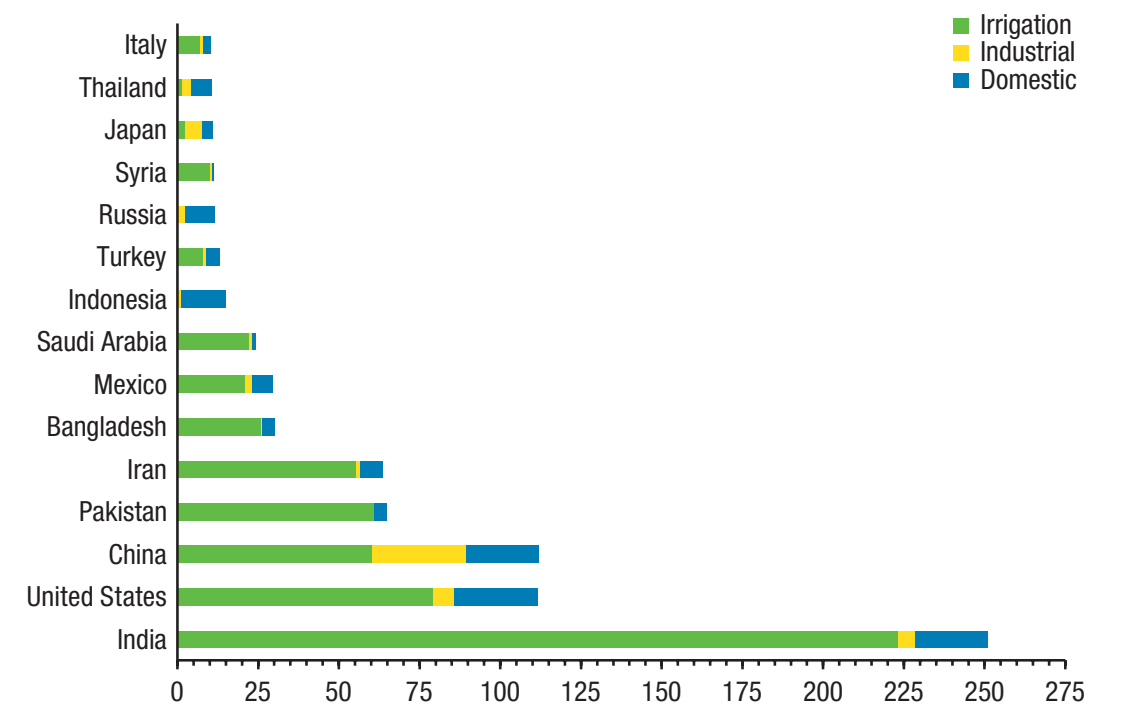

Source: Groundwater extraction statistics in Margat and van der Gun (2013).

for irrigation. Pakistan and Iran are the fourth and fifth largest groundwater users, abstracting an estimated 65 cubic kilometers and 63 cubic kilometers in 2010, again largely for irrigation (Margat and van der Gun 2013).

Intensive groundwater irrigation has led to groundwater depletion in many arid and semiarid agricultural regions, where groundwater is extracted at rates exceeding groundwater recharge (Wada et al. 2010; Wada et al. 2012; Gleeson et al. 2012; Döll et al. 2014). Groundwater tables have been declining at alarming rates in some of the world's major aquifers (Rodell, Velicogna, and Famiglietti 2009; Wada et al. 2010; Jiménez et al. 2011; Gleeson et al. 2012; Cao et al. 2013; Long et al. 2016; Tang et al. 2017). Many of those depleted aquifers overlap with the world's most important breadbaskets (Villholth et al. 2016). Sustained groundwater overdraft puts future irrigated food production at risk and leads to undesirable environmental consequences, including land subsidence and seawater intrusion, which can have profound social and environmental impacts (Giordano 2009; Kløve et al. 2011; Medellín-Azuara et al. 2015).

\section{Water Pollution}

Water pollution from the overuse of agricultural chemicals is a growing, but largely unaddressed, threat to public health and water-related ecosystems. 
FIGURE 20.5 Estimated nutrient-loading intensity from agricultural land in the base year (2000)

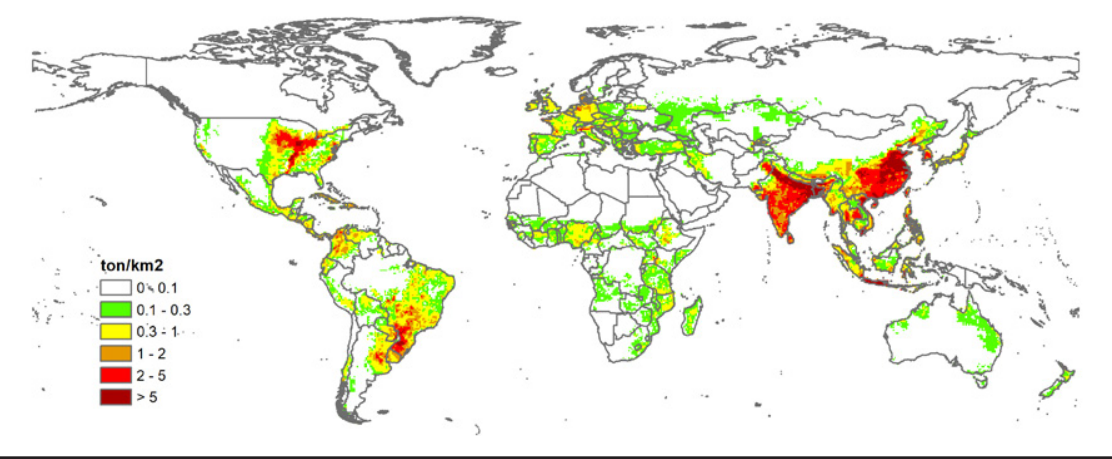

Source: Xie and Ringler (2017).

Major pollutants from agricultural sources that lead to water quality deterioration include nutrients, pesticides, and a family of emerging contaminants such as hormones and feed additives (Mateo-Sagasta et al. 2017). While most water pollution studies are carried out at small scales due to data constraints and the role of local biophysical environments in shaping pollution levels, a few macronutrient pollution studies have been implemented at larger scales, because sources and impacts are relatively well-known and data are more readily available. Nitrogen pollution, which has been clearly linked to agricultural practices, is harmful for ecosystems, causing algal blooms and dead zones in coastal areas, such as the hypoxia in the Gulf of Mexico (Good and Beatty 2011). Nitrates in drinking water can decrease the ability of blood to carry oxygen, which can be fatal for infants.

Xie and Ringler (2017) assessed the likely future development of global nitrogen $(\mathrm{N})$ and phosphorous $(\mathrm{P})$ loadings from agricultural production under alternative socioeconomic, climate, and technological change scenarios. They estimate global $\mathrm{N}$ loadings from agriculture around the year 2000 at 46 million metric tons per year and P loadings at 2.7 million metric tons per year. An example of the modeled distribution of $\mathrm{N}$ loadings across the globe is presented in Figure 20.5. Global N and P loadings are projected to rapidly increase under all climate and socioeconomic scenarios with $\mathrm{N}$ loadings growing to between 62 million metric tons and 81 million metric tons. Patterns of change are similar for projections of $\mathrm{P}$ loadings but with lower overall projected growth, and a total range of 2.8 million metric tons to 3.4 million metric tons per year. Moreover, growth in pollution is projected to be fastest in the group of low-income developing countries, with a projected increase of 
up to 118 percent for $\mathrm{N}$ loadings and up to 47 percent for $\mathrm{P}$ loadings. While nutrient-loading levels are currently largest in the Asia region (Figure 20.5), rates of growth are fastest in Africa.

It is much more challenging to assess the impacts of micropollutants, such as pesticides and emerging contaminants, as data on sources of pollution and their impacts are lacking, transformation processes of individual components and mixtures of various components are not always known, and no data are collected on most of these pollutants. Moreover, in many countries only some micropollutants are regulated and many are not treated. It is thus difficult to monitor and model the share of pesticide components and other micropollutants that reach water bodies and to design broad mitigation measures (Schwarzenbach et al. 2010).

Water pollution can occur at recommended levels of agrochemical applications, as only a share of chemicals are taken up by plants. Pollution levels can be larger if farms are near water bodies or if large rainfall events wash chemicals into water bodies. At the same time overuse of chemicals occurs and is linked to farmers' risk aversion, fertilizer subsidies (often for nitrogen, which can lead to unbalanced use of application levels), underinvestment in extension services and related overreliance on agrodealers for advice on chemicals, and farmers' lack of knowledge regarding pesticide use when new plant diseases occur (Borin et al. 2005; Jin, Bluemling, and Mol 2015; Good and Beatty 2011).

\section{Water Variability}

Water variability, or hydrologic variability, is a natural phenomenon driven by climate variability. When manifesting in extreme hydroclimatic events such as floods and droughts, water variability can damage crops (Ray et al. 2015), destroy livelihoods, and adversely affect economic growth (Brown and Lall 2006; Thurlow, Zhu, and Diao 2012). Owing to agriculture's strong reliance on and direct exposure to weather, management of water variability is a key concern for food production. According to Lesk, Rowhani, and Ramankutty (2016), globally, droughts and extreme heat alone reduced cereal production by 9 percent to 10 percent during 1964 through 2007. Moreover, agricultural production in developing countries is more vulnerable to weather shocks, due to the sector's lower capital investment and knowledge intensity and associated coping capacity. In recent years, almost one-quarter of weather-related damages has been in the agricultural sector in developing countries (FAO 2015).

Figure 20.6 displays mean annual runoff and the coefficient of variation of annual runoff at a 0.5 -degree resolution. Annual runoff depth is a 
FIGURE 20.6 Mean annual runoff and coefficient of variation (CV) of annual runoff

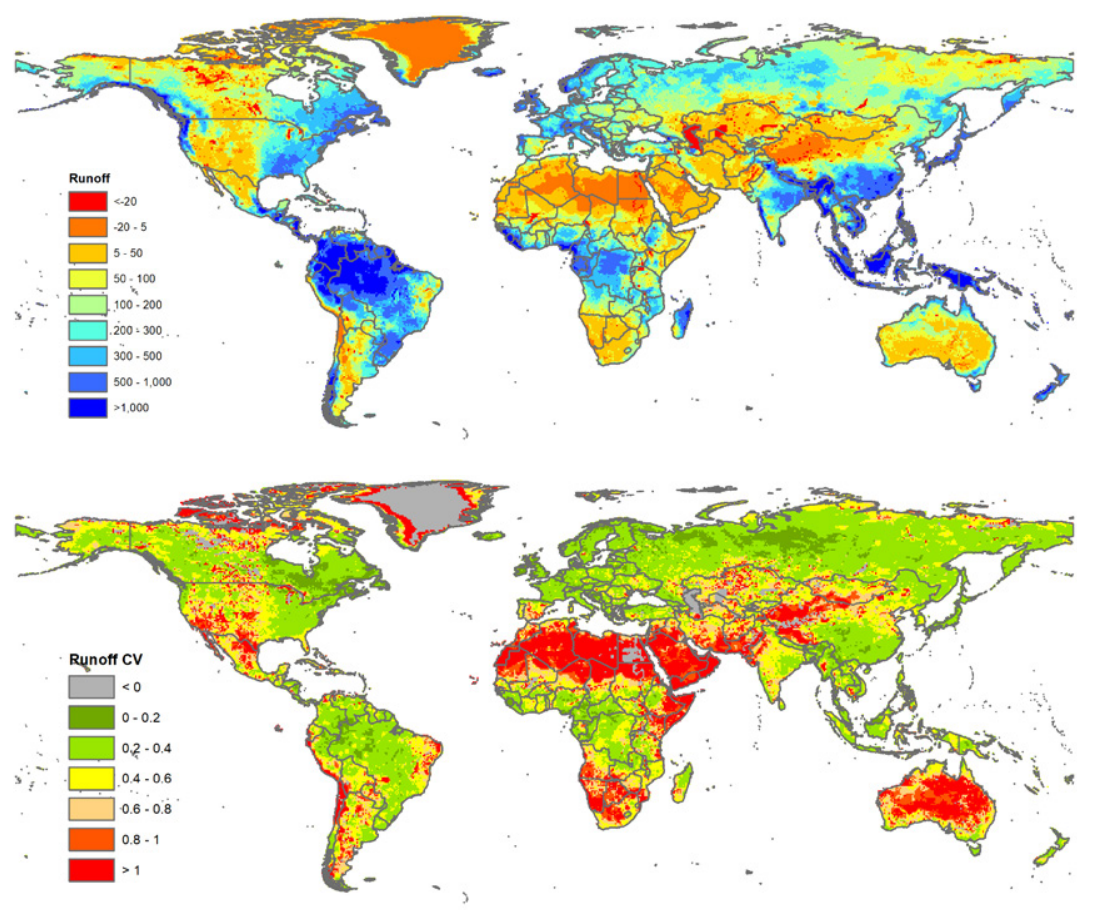

Source: IMPACT Global Hydrological Simulation for the 1951-2000 period.

Note: In open-water bodies grid cells where actual evapotranspiration exceeds precipitation runoff values are negative. Runoff is in $\mathrm{mm}$ per year.

measure of water availability. The coefficient of variation $(\mathrm{CV})$ is the standard deviation of annual runoff divided by mean annual runoff and is a measure of interannual water variability. Strong water variability exists in many regions of the world, especially arid and semiarid regions such as southern Africa, the Middle East and North Africa, the southwestern United States, and southern Latin America. Poorer countries generally exhibit higher water variability (Grey and Sadoff 2007). While floods can sweep away crops and properties, and pollute domestic water sources, droughts can cause crop losses through reducing both harvested areas and crop yields (Lesk, Rowhani, and Ramankutty 2016). In much of Africa south of the Sahara, where agriculture remains largely rainfed, interannual climate variability significantly affects agricultural GDP and total GDP. Increasing water variability associated with climate change is expected to increase pressure on food production. Existing and growing uncertainties regarding precipitation are adversely affecting 
investments in agricultural productivity, particularly in Africa south of the Sahara where investment in irrigation infrastructure is especially low (Cooper et al. 2008).

Food production and prices can be affected by water variability and climatic shocks in significant ways, both at the local and global levels. Climate change projections generally only assess the mean impact of changes in temperatures and precipitation and do not consider changes in the variability of climate. To assess the role of irrigation in addressing water variability, we simulate the impact of climate variability and change on maize production and net trade in maize, the key staple crop in southern Africa. Southern Africa is of particular interest to the analysis of climate variability due to its overall water scarcity and high variability of water availability (see Figure 20.6; Conway et al. 2015). We then simulate the potential of expanded irrigation in southern Africa to reduce the adverse impact of climate variability and change, projecting a 50 percent increase in irrigated area in the region (using the scenario introduced earlier in the chapter for the southern African region only).

Figure 20.7 presents the cumulative distribution functions (CDF) for production and net trade of maize under climate variability and change, compared to a NoCC scenario as well as the benefits from irrigation expansion for maize production and trade in southern Africa. The probability that maize production falls below 35 million metric tons increases from 13.2 percent under the NoCC scenario to 20.0 percent under the HGEM scenario. Conversely, if irrigated area is expanded in southern Africa, the probability for maize production to decline below 35 million metric tons declines to 6.9 percent.

In terms of maize trade, under the HGEM climate change scenario, the probability and range of maize imports in southern Africa declines from 16 million metric tons to 31 million metric tons under the NoCC scenario to 9 million metric tons to 23 million metric tons as a result of climate change, which puts pressure on maize prices, resulting in a decline in demand for maize. With substantial expansion of irrigated area, the region would see a further shift to the right with a range of yet lower net imports of 5 million metric tons to 21 million metric tons. In this case, net imports would decline due to the rapid expansion in irrigated area in the southern African region, which would reduce the pressure on maize prices and also reduce the need to import maize.

The key response to water variability has been investment in water storage. Historically, most investment has been in reservoirs. Such reservoirs are increasingly being built as multipurpose systems, storing water for irrigation, 
FIGURE 20.7 Variability in maize production and net trade, plotted as cumulative distribution functions, southern Africa, 2050
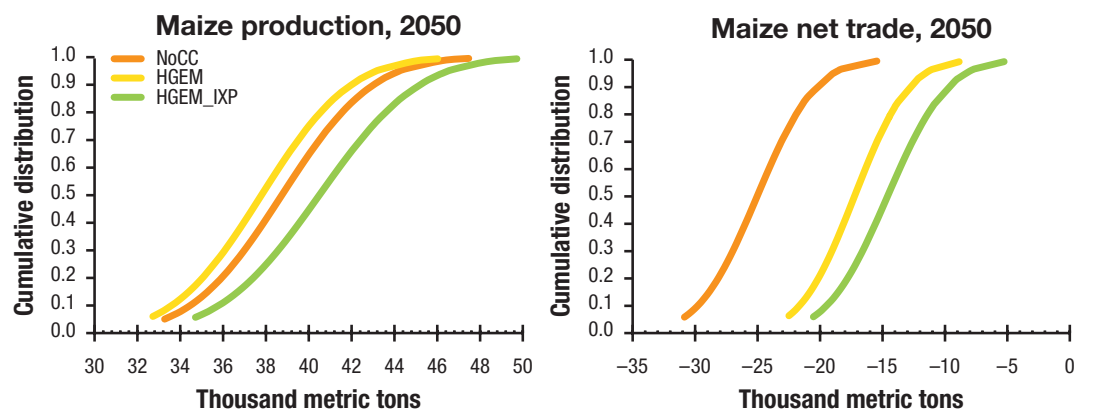

Source: Authors' estimates from IMPACT simulations.

Note: $\mathrm{NoCC}=$ no climate change; HGEM = climate change from Hadley Centre Global Environmental Model; IXP = irrigation expansion.

municipal-industrial uses, hydroelectricity production and flood control, and sometimes reservoir fisheries, and to ensure timely releases for environmental flow purposes. According to the International Energy Agency (IEA 2016), power production from reservoirs accounted for more than 85 percent of global renewable electricity generation in 2015. However, such reservoirs, or gray storage, often affect the migration patterns and spawning patterns of fish; change hydrological regimes, temperature, and flows of rivers; and can disrupt nutrient and sediment flows for fish and other aquatic resources.

A more holistic consideration of the storage continuum is now increasingly considered. This continuum ranges from natural water storage underground, in the soil and in water bodies to gray infrastructure, and includes small and large reservoirs (McCartney and Smakhtin 2010). A relatively recent measure to enhance the natural storage capacity of groundwater for both reduced flooding and increased availability of water during the dry season, for irrigation and other purposes, is managed aquifer recharge (MAR). MAR is the intentional recharge of water to aquifers for subsequent recovery or environmental benefit. Dillon et al. (2019) estimate that MAR has accelerated at a rate of 5 percent per year and has reached an estimated 10 cubic kilometers per year, equivalent to more than 2 percent of groundwater extraction in countries reporting MAR. India and the United States, large extractors of groundwater, also report the largest MAR capacity.

There are measures to directly reduce water variability in irrigation systems, for example, through improved irrigation-scheduling tools that can 
reduce excess water application. These tools, including soil moisture and yield sensors, are increasingly linked to large databases that trigger irrigation applications or other agricultural management interventions. Improved climate forecasting tools, drought-monitoring bulletins, and apps that provide realtime and near-future information on precipitation, temperatures, droughts, and crop prices are further tools that help farmers manage climate, water, and associated food production risks (Rodrigues et al. 2016).

\section{Conclusion and Policy Recommendations}

Water scarcity is a reality today for many people on the globe, and this scarcity is particularly felt in the agriculture sector, which is often the user of last resort. Driven by population and economic growth, the demand for water is expected to substantially increase in nearly all developing countries and many developed countries over the coming decades. While domestic and industrial water demands continue to grow faster than irrigation water demands, agricultural water use will remain the largest consumptive use sector out to 2050 . Climate change adds an additional layer of complexities to the water and food challenges in the future, and considerable uncertainties exist in climate model projections and associated projections of water availability and resulting gaps between demands and supplies. However, there is little doubt that the adverse effects of climate change on water most directly affect the agriculture sector, where growing more food to meet the caloric and nutrition demands of an increasing population will require that more water is used for food production unless significant water savings (that is, crop per drop) can be achieved. Increasing water productivity can be achieved both in the water and irrigation sectors but also through a host of other measures.

Policies and strategies in the irrigation sector that can help support water security for food production in developing countries include removal of restrictions to the import of advanced irrigation technologies, and increased investment in extension services and other knowledge management platforms geared toward the use of often complex irrigation technologies as well as for associated knowledge areas in integrated pest management, agrochemical applications, and climate information services. Knowledge platforms on advanced irrigation technologies can also directly address water pollution concerns. Drip irrigation systems can apply agrochemicals with the irrigation water in more precise doses than traditional application mechanisms can provide - that is, through fertigation-and can furthermore enhance the quality of horticultural products. Various precision-agricultural technologies, such 
as soil moisture sensors or simple wetting-front detectors, can provide guidance to farmers on when irrigation can improve crop yields and when not (for example, Stirzaker 2003). To achieve savings through direct irrigation interventions, it will be essential to further advance measurements of irrigation water use through remote sensing technologies, combined with field validation. Several research and private consultancy groups continue to advance measurements of evapotranspiration from space (Bastiaanssen, Molden, and Makin 2000).

Importantly, investments in advanced irrigation technologies, such as drip or sprinklers, without proper assessment of water resources and flows, and without institutions that put a cap on withdrawals for agriculture, might well increase total irrigation water consumption, which is also called the "paradox of irrigation efficiency" (Rosegrant, Ringler, and Zhu 2009; Ringler 2017; Grafton et al. 2018). In rainfed environments, key measures to improve wateruse efficiency when irrigation is not available include conservation agriculture, improved weeding, reduced tillage, and application of mulches. Governments need to strengthen investments in crop breeding for increased plant transpiration efficiency. Investment in agricultural research in this and other areas continue to fall short of research investments in other sectors like health. Moreover, the development of drought- and heat-stress-tolerant varieties of key food crops as well as submergence-tolerant varieties for coastal ecoregions can further improve the productivity and efficiency of irrigation applications.

In addition to investment in technologies, growing reliance on, and increased competition over shared water resources requires the strengthening of water management and allocation institutions. Such institutions include river basin organizations at the basin or watershed level, water user associations at the level of irrigation systems, and community rules or regulations for using shared aquifer resources. Mekonnen, Channa, and Ringler (2015) found that the existence of effective water user organizations improved agricultural productivity of farmers at the tail end of irrigation canals. At the community level, pilot studies in India have shown that collective groundwater management facilitated by experimental games can be effective in improving local groundwater governance (Meinzen-Dick et al. 2018). These are now being scaled up to several thousand communities across multiple Indian states.

Many of these technologies and institutions can also help remediate key challenges to irrigation expansion: water pollution and groundwater depletion. However, this requires increased investment in these often invisible environmental impacts. Unless serious investments and actions are taken toward addressing agricultural water pollution and groundwater depletion, clean water 
will be increasingly difficult to find in the breadbaskets of Asia and the rapidly growing farming centers of Africa south of the Sahara. Solutions exist and include enhanced nutrient-use efficiency, phasing out fertilizer subsidies, no-till or reduced tillage, crop rotations and other conservation measures, and closing the nutrient cycle, but both enforcement of regulation and economic incentives to use fertilizers and pesticides more judiciously are currently lacking (Good and Beatty 2011; IFPRI and Veolia 2015; Sun et al. 2012; Huang et al. 2015).

\section{References}

Alcamo, J., and T. Henrichs. 2002. "Critical Regions: A Model-Based Estimation of World Water Resources Sensitive to Global Changes." Aquatic Sciences 64 (4): 352-362.

Bastiaanssen, W. G. M., D. J. Molden, and I. W. Makin. 2000. "Remote Sensing for Irrigated Agriculture: Examples from Research and Possible Applications." Agricultural Water Management 46 (2): 137-155.

Bates, B. C., Z. W. Kundzewicz, S. Wu, and J. P. Palutikof, eds. 2008. "Climate Change and Water." Technical Paper of the Intergovernmental Panel on Climate Change, IPCC Secretariat, Geneva.

Borin, M., M. Vianello, F. Morari, and G. Zanin. 2005. "Effectiveness of Buffer Strips in Removing Pollutants in Runoff from a Cultivated Field in North-East Italy." Agriculture, Ecosystems \& Environment 105 (1-2): 101-114.

Brown, C., and U. Lall. 2006. "Water and Economic Development: The Role of Variability and a Framework for Resilience." Natural Resources Forum 30: 306-317.

Cao, G., C. Zheng, B. R. Scanlon, J. Liu, and W. Li. 2013. "Use of Flow Modeling to Assess Sustainability of Groundwater Resources in the North China Plain.” Water Resources Research 49 (1): 159-175.

Conway, D., E. Archer van Garderen, D. Deryng et al. 2015. "Climate and Southern Africa’s WaterEnergy-Food Nexus." Nature Climate Change 5 (9): 837-846.

Cooper, P. J. M., J. Dimes, K. P. C. Rao, B. Shapiro, B. Shiferaw, and S. Twomlow. 2008. "Coping Better with Current Climatic Variability in the Rain-Fed Farming Systems of Sub-Saharan Africa: An Essential First Step in Adapting to Future Climate Change?" Agricultural Ecosystems and Environment 126 (1-2): 24-35.

Dillon, P., P. Stuyfzand, T. Grischek et al. 2019. "Sixty Years of Global Progress in Managed Aquifer Recharge.” Journal of Hydrogeology 27: 1. 
Döll, P., H. Müller Schmied, C. Schuh, F. T. Portmann, and A. Eicker. 2014. “Global-Scale Assessment of Groundwater Depletion and Related Groundwater Abstractions: Combining Hydrological Modeling with Information from Well Observations and GRACE Satellites." Water Resources Research 50: 1-23.

FAO (Food and Agriculture Organization of the United Nations). 2011. The State of the World's Land and Water Resources for Food and Agriculture (SOLAW): Managing Systems at Risk. Rome.

-2015. Impact of Natural Hazards and Disasters on Agriculture and Food Security and Nutrition. Rome.

FAO AQUASTAT. 2019. FAO AQUASTAT Main Database. Accessed September 26, 2019. www .fao.org/nr/water/aquastat/data/query/index.html?lang=en.

Fishman, R., M. Jain, and A. Kishore. 2013. "Patterns of Migration, Water Scarcity and Caste in Rural Northern Gujarat." London: IGC.

Giordano, M. 2009. "Global Groundwater? Issues and Solutions." Annual Review of Environmental Resources 34: 153-178.

Gleeson, T., K. M. Befus, S. Jasechko, E. Luijendijk, and M. B. Cardenas. 2015. “The Global Volume and Distribution of Modern Groundwater." National Geoscience Advance (November): 1-15.

Gleeson, T., Y. Wada, M. F. P. Bierkens, and L. P. H. van Beek. 2012. "Water Balance of Global Aquifers Revealed by Groundwater Footprint.” Nature 488 (7410): 197-200.

Good, A. G., and P. H. Beatty. 2011. "Fertilizing Nature: A Tragedy of Excess in the Commons." PLoS Biology 9 (8): p.e1001124.

Grafton, R. Q., J. Williams, C. J. Perry et al. 2018. “The Paradox of Irrigation Efficiency.” Science 361 (6404): 748-750.

Grey, D., and C. W. Sadoff. 2007. "Sink or Swim? Water Security for Growth and Development.” Water Policy 9 (6): 545-571.

Huang, J., Z. Huang, X. Jia, R. Hu, and C. Xiang. 2015. “Long-Term Reduction of Nitrogen Fertilizer Use Through Knowledge Training in Rice Production in China." Agricultural Systems 135: 105-111.

IEA (International Energy Agency). 2016. Electricity Data Browser. Accessed October 2016. www .eia.gov/electricity/data/browser/.

IFPRI (International Food Policy Research Institute) and Veolia. 2015. "The Murky Future of Global Water Quality. New Global Study Projects Rapid Deterioration in Water Quality.” White paper. IFPRI, Washington, DC. 
Jiménez, C., et al. 2011. "Global Intercomparison of 12 Land Surface Heat Flux Estimates." Journal of Geophysical Research 116 (D2): 1-27.

Jin, S., B. Bluemling, and A. P. J. Mol. 2015. "Information, Trust and Pesticide Overuse: Interaction between Retailers and Cotton Farmers in China." NJAS-Wageningen Journal of Life Sciences 72-73: 23-32.

Jury, W. A., and H. Vaux. 2005. "The Role of Science in Solving the World's Emerging Water Problems." Proceedings of the National Academy of Sciences 102 (44): 15715-15720.

Kløve, B., et al. 2011. "Groundwater Dependent Ecosystems. Part II. Ecosystem Services and Management in Europe under Risk of Climate Change and Land Use Intensification." Environmental Science Policy 14 (7): 782-793.

Lesk, C., P. Rowhani, and N. Ramankutty. 2016. "Influence of Extreme Weather Disasters on Global Crop Production.” Nature 529 (7584): 84-87.

Long, D., X. Chen, B. R. Scanlon et al. 2016. "Have GRACE Satellites Overestimated Groundwater Depletion in the Northwest India Aquifer?” Science Rep. 6 (April): 24398.

Malabo Montpellier Panel. 2018. Water-Wise: Smart Irrigation Strategies for Africa. Dakar: IFPRI.

Margat, J. F., and J. van der Gun. 2013. Groundwater around the World: A Geographic Synopsis. New York: CRC Press.

Mateo-Sagasta, J., S. M. Zadeh, H. Turral, and J. Burke. 2017. "Water Pollution from Agriculture: A Global Review." Food and Agriculture Organization of the United Nations and the International Water Management Institute, Rome.

McCartney, M., and V. Smakhtin. 2010. Water Storage in an Era of Climate Change: Addressing the Challenge of Increasing Rainfall Variability. Blue paper, IWMI Reports 212430. Colombo, Sri Lanka: International Water Management Institute.

Medellín-Azuara, J., D. MacEwan, R. E. Howitt et al. 2015. "Hydro-Economic Analysis of Groundwater Pumping for Irrigated Agriculture in California's Central Valley, USA.” Journal of Hydrogeology 23 (6): 1205-1216.

Mehta, L., T. Oweis, C. Ringler, and S. Varghese. 2019. Water for Food Security, Nutrition and Social Justice. New York: Routledge.

Meinzen-Dick, R. S., M. Janssen, S. Kandikuppa, R. Chaturvedi, K. Rao, and S. Theis. 2018. "Playing Games to Save Water: Collective Action Games for Groundwater Management in Andhra Pradesh, India." World Development 107 (July 2018): 40-53.

Mekonnen, D., H. Channa, and C. Ringler. 2015. “The Impact of Water Users' Associations on the Productivity of Irrigated Agriculture in Pakistani Punjab." Water International 40 (5-6): 733-747. Special Issue: Sustainability in the Water-Energy-Food Nexus. 
Mekonnen, M. M., and A. Y. Hoekstra. 2016. "Four Billion People Facing Severe Water Scarcity.” Science Advances 2 (2): p.e1500323.

Mukherji, A., and A. Das. 2014. "The Political Economy of Metering Agricultural Tube Wells in West Bengal, India." Water International 39 (5): 671-685.

Oki, T., and S. Kanae. 2006. "Global Hydrological Cycles and World Water Resources." Science 313 (5790): 1068-1072.

Olmstead, S. M. 2013. "Climate Change Adaptation and Water Resource Management: A Review of the Literature." Energy Economics 46.

Ray, D. K., J. S. Gerber, G. K. MacDonald, and P. C. West. 2015. "Climate Variation Explains a Third of Global Crop Yield Variability." Nature Communications (6): 5989.

Ringler, C. 2017. Investment in Irrigation for Global Food Security. IFPRI Policy Note. Washington, DC: IFPRI.

Ringler, C., T. Zhu, S. Gruber et al. 2016. "Role of Water Security for Agricultural and Economic Development-Concepts and Global Scenarios." In Handbook on Water Security, edited by C. Pahl-Wostl, J. Gupta, and A. Bhaduri, 183-200. Cheltenham, UK: Edward Elgar Publishing Ltd.

Robinson, S., D. Mason d'Croz, S. Islam et al. 2015. The International Model for Policy Analysis of Agricultural Commodities and Trade (IMPACT): Model Description for Version 3. IFPRI Discussion Paper 1483. Washington, DC: IFPRI.

Rodell, M., I. Velicogna, and J. S. Famiglietti. 2009. "Satellite-Based Estimates of Groundwater Depletion in India."Nature 460 (7258): 999-1002.

Rodrigues, J., J. Thurlow, W. Landman, C. Ringler, R. Robertson, and T. Zhu. 2016. The Economic Value of Seasonal Forecasts: Stochastic Economy-Wide Analysis for East Africa. IFPRI Discussion Paper 1546. Washington, DC: IFPRI.

Rosegrant, M. W., C. Ringler, and T. Zhu. 2009. “Water for Agriculture: Maintaining Food Security under Growing Scarcity.” Annual Review of Environmental Resources 34: 205-222.

Schwarzenbach, R. P., T. Egli, T. B. Hofstetter, U. von Gunten, and B. Wehrli. 2010. "Global Water Pollution and Human Health.” Annual Review of Environment and Resources 35: 109-136.

Shah, T., J. Burke, K. Villholth, M. Angelica, and E. Custodio et al. 2007. "Groundwater: A Global Assessment of Scale and Significance.” In Water for Food, Water for Life: A Comprehensive Assessment of Water Management in Agriculture, edited by D. Molden, 395-423. London and Colombo, Sri Lanka: Earthscan.

Shiklomanov, I. A. 1993. "World Fresh Water Resources." In Water in Crisis: A Guide to the World's Fresh Water Resources, 13-24. Oxford: Oxford University Press. 
Siebert, S., J. Burke, J. M. Faures, K. Frenken, J. Hoogeveen, P. Döll, and F. T. Portmann. 2010.

"Groundwater Use for Irrigation-A Global Inventory." Hydrology Earth Systems Science 14 (10): $1863-1880$.

Sojka, R. E., D. L. Bjorneberg, and J. A. Entry. 2002. “Irrigation: An Historical Perspective.” Encyclopedia of Soil Science (1): 745-749.

Stirzaker, R. J. 2003. "When to Turn the Water Off: Scheduling Micro-Irrigation with a Wetting Front Detector." Irrigation Science 22 (3-4): 177-185.

Sun, B., L. Zhang, L. Yang, F. Zhang, D. Norse, and Z. Zhu. 2012. "Agricultural Non-point Source Pollution in China: Causes and Mitigation Measures." Ambio 41 (4):370-379.

Tang, Y., M. Hooshyar, T. Zhu, C. Ringler, A. Y. Sun, D. Long, and D. Wang. 2017.

"Reconstructing Annual Groundwater Storage Changes in a Large-Scale Irrigation Region Using GRACE Data and Budyko Model." Journal of Hydrology 551: 397-406.

Thurlow, J., T. Zhu, and X. Diao. 2012. "Current Climate Variability and Future Climate Change: Estimated Growth and Poverty Impacts for Zambia." Review of Developmental Economics 16 (3): 394-411.

Vicuña, S., J. McPhee, and R. Garreaud. 2012. "Agriculture Vulnerability to Climate Change in a Snowmelt-Driven Basin in Semiarid Chile." Journal of Water Resources, Planning, and Management 138 (5): 431-441.

Villholth, K. G., A. Sood, N. Liyanage, T. Zhu, and Y. Wada. 2016. "Global Food Production Share from Sustainable and Unsustainable Groundwater Use." In The 43rd International Association of Hydrogeologists Congress "Groundwater and Society: 60 years of IAH."

Montpellier, France: IAH.

Wada, Y., L. P. H. van Beek, and M. F. P. Bierkens. 2012. "Nonsustainable Groundwater Sustaining Irrigation: A Global Assessment." Water Resources Research 48 (November).

Wada, Y., L. P. H. van Beek, C. M. van Kempen, J. W. T. M. Reckman, S. Vasak, and M. F. P. Bierkens. 2010. "Global Depletion of Groundwater Resources." Geophysical Research Letters $37(20): 1-5$.

World Bank. 1986. Pakistan - Salinity Control and Reclamation (SCARP) Transition Pilot Project. Washington, DC.

WWAP (UNESCO World Water Assessment Programme). 2016. The United Nations World Water Development Report 2016: Water and Jobs. Paris: UNESCO.

- 2019. The United Nations World Water Development Report 2019: Leaving No One Behind. Paris: UNESCO.

Xie, H., and C. Ringler. 2017. "Agricultural Nutrient Loadings to the Freshwater Environment: The Role of Climate Change and Socioeconomic Change." Environmental Research Letters (12): 104008. 